\title{
BUSINESS OPERATIONS OF ENTREPRENEURIAL STORES IN THE FIELD OF AGRICULTURE IN THE REPUBLIC OF SERBIA IN THE PERIOD 2015-2019
}

\author{
Aleksandra Fedajev ${ }^{1}$, Raica Milićević ${ }^{2}$, Milica Cvetković ${ }^{3}$,Vladan Cogoljević ${ }^{4}$ \\ *Corresponding author E-mail: raica.milicevic@vspep.edu.rs
}

A R T I C L E I N F O
Review Article
Received: 22 March 2021
Accepted: 02 June 2021
doi:10.5937/ekoPolj2102547F
UDC 631.1/.7:347.2(497.11)"2
015/2019"'

Keywords:

agriculture, entrepreneurship, ratio analysis, PROMETHEE method, entropy method

JEL: L26, M21, O13, P32,Q11,Q18, L21

\begin{abstract}
A B S T R A C T
Entrepreneurship development represents one of the very important factors in the development of economies in transition. Bearing in mind that most of these economies still have a significant share of agricultural products in the structure of production and exports, special attention should be paid to the development of entrepreneurship in the field of agriculture. The research results in this paper indicate that the share of entrepreneurs in this business activity in the total number of entrepreneurs is extremely low, as well as that their share in employment in state subventions is also low, and it can be concluded that entrepreneurship in agriculture is still not sufficiently developed. By using PROMETHEE and the entropy method, a comparative analysis of the performance of entrepreneurs in this sector and entrepreneurs in other business activities within the real sector of the economy was performed and it was concluded that the key limitations in the business operations of these entrepreneurs are inefficient funds management and high indebtedness.
\end{abstract}

(C) 2021 EA. All rights reserved.

1 Aleksandra Fedajev, Ph.D., Associate Professor, University of Belgrade, Technical faculty in Bor, Vojske Jugoslavije 12, Phone: +381 30424 555, E-mail: afedajev@ttbor.bg.ac.rs, ORCID ID (https://orcid.org/0000-0002-6974-6631)

2 Raica Milićević, Teaching Assistant, Faculty of Business Economics and Entrepreneurship, 8 Mitropolita Petra st., Phone: +381 63456 320, E-mail: raica.milicevic@vspep.edu.rs, ORCID ID (https://orcid.org/0000-0002-8497-0711)

3 Milica Cvetković, Teaching Assistant, Business College of Applied Studies "Prof. Radomir Bojković, PhD”, 12 Topličina st., Kruševac, Phone: +381 6384896 19, E-mail: milica. cvetkovic85@yahoo.com, ORCID ID (https://orcid.org/0000-0002-1235-3570/)

4 Vladan Cogoljević, TeachingAssistant, Faculty ofBusiness Economics and Entrepreneurship, 8 Mitropolita Petra st., Phone: +381 6310220 40, E-mail: vladan.cogoljevic@vspep.edu. rs, ORCID ID (https://orcid.org/0000-0002-9019-7913) 


\section{Introduction}

In modern business conditions, the trend of increase and change in the structure of demand for agricultural products is increasingly pronounced. Such a situation on the world market requires market orientation of business entities operating in this business activity, in order to better respond to new market requirements. In that sense, it is necessary to create conditions for improving the competitiveness of the agricultural sector, which cannot be based only on low input prices (land, labour), but on greater application of knowledge and innovation in business operations. The current application of information technologies in agriculture in Serbia is modest, compared to the EU countries, primarily due to the unfavourable educational structure of agricultural producers, as well as limited financial resources, which significantly complicates the process of applying IT.

The crisis in the agricultural sector in the Republic of Serbia has been going on for many years. Insufficient use of the potential for the development of agricultural production is the result of a wrong systemic attitude towards the agricultural sector. Instead of investing in the development of this economic area with numerous comparative advantages, the process of disinvestment has been happening for a long time, which further causes the process of deagrarization and demographic emptying of villages. In addition, this industry has been further depleted by years of economic recession.

Agricultural production is exposed to numerous risks, such as natural disasters, unpredictable weather conditions, yield and price uncertainty, and it is estimated that these risks will increase in the future, due to global warming, genetic engineering in agriculture and pandemics of livestock diseases. These limitations and risks have a particularly negative effect on the business of entrepreneurs, which greatly affects the sustainability of their business. Entrepreneurs in the field of agriculture have significantly higher costs and lower productivity, compared to large business entities, due to insufficient application of technics and technology in production. Insufficient volume of own funds, limited access to external sources of financing, high costs of obtaining capital, complicated administrative procedures, insufficiently transparently defined credit conditions and problems in securing loans are also mentioned as limitations in the business operations of this group of business entities. Therefore, the state and local governments should create a stimulating business environment for the development of entrepreneurship in the agricultural sector and rural development in general, especially in underdeveloped regions of the Republic of Serbia. Implementation of necessary incentive measures in agriculture, accompanied by reforms of the judiciary and education, can strengthen agricultural entrepreneurship in Serbia in the long run by completely replacing the anachronistic structure from the end of the last century and by taking the country into a new phase of expansionary agricultural development. 
In this sense, the aim of this paper is to perform a comparative analysis of the business operations of agricultural entrepreneurs in relation to entrepreneurs operating in other business activities within the real sector in order to assess their position and the limitations they face in business operations and to define appropriate measures to improve their business operations. For this purpose, based on the ratio analysis of business operations of entrepreneurs in eight sectors that make up the real sector of the economy, which served as the basis for multicriteria analysis, conducted using the PROMETHEE method and entropy method.

\section{Key trends in agriculture and its contribution to the economic development of the Republic of Serbia}

Table 1 shows the movement of key indicators that indicate trends in the agricultural sector in the Republic of Serbia in the period 2015-2019.

Table 1. Key indicators of agricultural development in the Republic of Serbia in the period 2015-2019

\begin{tabular}{|l|l|l|l|l|l|}
\hline Year & $\begin{array}{l}\text { Real growth rates, } \\
\text { previous year } \\
100(\text { in\% })^{1}\end{array}$ & $\begin{array}{l}\text { Growth rate of GVA } \\
\text { per employee, previous } \\
\text { year= 100 }(\mathrm{u} \%)^{2}\end{array}$ & $\begin{array}{l}\text { Share in } \\
\text { employment } \\
(\text { in\% })^{1}\end{array}$ & $\begin{array}{l}\text { Share } \\
\text { in GDP } \\
(\text { in\% })^{1}\end{array}$ & $\begin{array}{l}\text { Share in } \\
\text { exports } \\
(\text { in\% })^{1}\end{array}$ \\
\hline 2015 & 2.2 & 3.40 & 1.94 & 6.7 & 7.06 \\
\hline 2016 & 7.5 & 5.64 & 1.73 & 6.8 & 7.15 \\
\hline 2017 & -11.4 & -6.99 & 1.67 & 6.0 & 5.93 \\
\hline 2018 & 15.1 & 22.53 & 1.59 & 6.3 & 5.44 \\
\hline 2019 & -1.6 & 2.03 & 1.47 & 6.0 & 6.10 \\
\hline
\end{tabular}

Source: Statistical Office of the Republic of Serbia, World Bank.

Based on the data in Table 1, it can be concluded that agricultural growth rates recorded significant variations during the observed five-year period, which was largely the result of the sensitivity of agricultural production to external factors and risks. A particularly pronounced decline in economic activity in this field was recorded in 2017. The reasons for such a low real growth rate in that year were multiple, and they related primarily to the drought that significantly threatened the production of corn and soybeans, frost that led to a drastic decline in plum production as one of the key export products and record low prices of raspberries in the world market. Significant growth was recorded the following year primarily on the basis of a low base in the previous year. At the end of the observed period, a decline in agricultural production of $1.6 \%$ was recorded for the reasons already mentioned. It is important to point out that the Corona virus pandemic did not leave significant consequences on the business operation of this sector in 2020 . This business activity is one of the few that has shown significant resilience to the crisis, given that during the first three quarters of 2020, an average growth rate of $4.5 \%$ was achieved. A similar trend of movement was recorded in the case of the growth rate of GVA per employee, which indicates that the level of productivity of agricultural production recorded significant oscillations in the observed period. Here also came to 
a break in productivity growth in 2017 , after which a growth of $22.53 \%$ was recorded. At the end of the observed period, a slight productivity growth of $2.03 \%$ was recorded. Slightly higher growth rates of this indicator in relation to the real growth of economic activity are the result of a continuous decrease in the number of employees in this business activity, as evidenced by the continuous decrease in the share of this business activity in total employment. At the same time, the share in employment was very modest and averaged $1.68 \%$ in the observed period.

Agriculture traditionally has a relatively high share in GDP creation. The average share of this business activity in GDP in the observed period was $6.36 \%$, although a slightly lower share was recorded during the last three observed years. The share in exports recorded a significant decrease in 2017 (which is certainly the result of reduced economic activity in that year) and by the end of the observed period it recorded a slightly lower share compared to the first two observed years. However, it is important to say that in 2019 there was recorded a slight increase in this indicator compared to the previous year, but also that during the Corona virus pandemic in 2020, this economic activity significantly contributed to exports, given that it had already achieved a share of $7.36 \%$ in the first three quarters of 2020 . It is possible to achieve mitigation of the effects of the pandemic on the Serbian economy by making better use of the potential for agricultural development. Improvement of the situation in this sector can significantly contribute to the improvement of the foreign trade balance, the reduction of public debt, the reduction of unemployment and the increase in the living standards of the population.

Having in mind the strategic importance that agriculture has for the development of the economy of the Republic of Serbia, but also the limitations it faces, the question of providing adequate state support that will contribute to its more dynamic development in the future logically arises.

\section{State support for the development of agriculture in the Republic of Serbia}

The Republic of Serbia has made certain efforts to prevent further lagging behind of agriculture in relation to other economic areas in the country, but also in relation to the surrounding countries. This, of course, is not possible without modernizing the production process through the application of modern science and technology in business operations, which requires significant investments. The problems in financing the agricultural sector are multiple and are the result of decisions made in the 20th century. The policy of depressed prices in the SFRY, sanctions of the international community, the disintegration of the SFRY and other socio-political factors influenced the volume of agricultural production to decrease significantly. Permanent solution of the problem of financing agrarians requires the adoption of a long-term plan for the development of agriculture and its consistent and continuous implementation.

The Law on Agriculture and Rural Development adopted the obligation to adopt the National Program for Agriculture, within which the medium- and short-term goals of the 
agricultural policy are defined. In that sense, in January 2018, the National Program for Agriculture for the period 2018-2020 was adopted, that represents a further elaboration of the Strategy of Agriculture and Rural Development of the Republic of Serbia for the period 2014-2024. This program, among other things, contains a financial plan by groups of measures for the development of agriculture by years. The plan does not include funds placed from the budget of the autonomous province or local self-government units. It should be noted that the planning of financial resources was carried out in accordance with the classification of the EU's Common Agricultural Policy (CAP). This way of defining the strategy is a necessary precondition for the continuation of the European integration process, because it shows the readiness of state bodies to consistently and gradually adopt the elements of the agricultural development model applied in the EU and it represents one of the most complex chapters in EU accession negotiations, so progress in this area would significantly contribute to progress in negotiations with the EU. This should provide conditions for more successful business operations of business entities in the field of agriculture, increase in the quality of agricultural products, stabilization of the markets for these products and generally more dynamic rural development in the long run. In order to see the role of the state in encouraging the development of agriculture according to the National Program for Agriculture for the period 2018-2020, Table 2 shows the scope and structure of state support to agriculture defined by the mentioned planning document.

Table 2. Amount of state support to agriculture by types of measures in the Republic of Serbia in 2018-2020 defined by the National Program for Agriculture for the period 2018-2020

\begin{tabular}{|l|r|r|r|}
\hline \multirow{2}{*}{ Type of support } & \multicolumn{4}{|l|}{ Amount of support in million RSD } \\
\cline { 2 - 5 } & $\mathbf{2 0 1 8}$ & $\mathbf{2 0 1 9}$ & $\mathbf{2 0 2 0}$ \\
\hline Direct payments & 2,268 & 21,784 & 22,307 \\
\hline Market regulation measures & - & - & 438 \\
\hline Special incentives & 255 & 255 & 255 \\
\hline Credit support & 800 & 800 & 800 \\
\hline In total & $\mathbf{2 2 , 3 2 4}$ & $\mathbf{2 2 , 8 3 9}$ & $\mathbf{2 3 , 8 0 0}$ \\
\hline
\end{tabular}

Source: National Program for Agriculture for the period 2018-2020

Based on the data from Table 2, it can be concluded that direct payments are the most important form of incentives in agriculture and rural development, given that on average almost $95 \%$ of funds are intended for this type of support. Direct payments are primarily aimed at stabilizing producers' incomes, but also at solving the problem of low productivity (due to mostly extensive agricultural production), poorly developed market and inefficient and inadequate use of natural resources. For other planned types of support, only $5.2 \%$ of the total planned funds in the observed three-year period were allocated. During the first two years, the use of measures related to market regulation was not planned, while in 2020, 438 million dinars were planned to be allocated for these purposes, that is, $1.84 \%$ of the allocated funds for that year. It was planned to allocate 225 million dinars evenly every year for special incentives, and 800 million dollars for credit support. 
In addition to the structure of incentive measures provided by the National Program for Agriculture, it is very important to consider the level of subventions in agriculture, as well as their share in total expenses and budget expenditures. In that sense, Table 3 shows the movement of subventions in agriculture provided by the Law on Budget by years in the period 2015-2021.

Table 3. Trend of movement of subventions in agriculture in the Republic of Serbia in the period 2015-2021

\begin{tabular}{|l|l|l|l|r|r|}
\hline Year & $\begin{array}{l}\text { Total expenses } \\
\text { and budget } \\
\text { expenditures (in } \\
\text { 000 RSD) }\end{array}$ & $\begin{array}{l}\text { Subventions in } \\
\text { agriculture (in } \\
\text { 000 RSD) }\end{array}$ & $\begin{array}{l}\text { Change in the value } \\
\text { of subventions in } \\
\text { agriculture compare } \\
\text { to the previous year } \\
\text { in\%) }\end{array}$ & Share & $\begin{array}{l}\text { Change in share } \\
\text { compared to the } \\
\text { previous year } \\
\text { (in\%) }\end{array}$ \\
\hline 2015 & $1,115,731,682$ & $28,063,951$ & - & 2.52 & - \\
\hline 2016 & $1,119,194,196$ & $27,951,498$ & -0.40 & 2.50 & -0.71 \\
\hline 2017 & $1,161,983,504$ & $31,600,710$ & 13.06 & 2.72 & 8.89 \\
\hline 2018 & $1,206,848,355$ & $34,315,130$ & 8.59 & 2.84 & 4.55 \\
\hline 2019 & $1,269,091,337$ & $41,580,757$ & 21.17 & 3.28 & 15.23 \\
\hline 2020 & $1,334,681,031$ & $41,008,753$ & -1.38 & 3.07 & -6.22 \\
\hline 2021 & $1,514,823,614$ & $41,865,313$ & 2.09 & 2.76 & -10.05 \\
\hline
\end{tabular}

Source: Author's calculation based on data from the Law on Budget for the respective years, available at: https://www.mpravde.gov.rs/sr/tekst/11523/zakon-o-budzetu-republike-srbije-.php

The data in Table 3 indicate that the amount of subventions in agriculture was continuously increasing in the period 2016-2019, with the exception of 2020, when there was recorded a decline in allocated funds for subventions of $1.38 \%$. For the current 2021, the budget has envisaged the allocation of a slightly higher amount of subventions $(2.09 \%)$, in order to support the economic activity of business activity which managed to maintain a satisfactory level of production even in the conditions of the Corona virus pandemic. It is interesting to point out that in 2017 , when this business activity recorded a significant decline due to unfavourable production conditions, the level of subventions to agriculture increased by as much as $13.06 \%$. However, the largest increase in the amount of subventions was recorded in $2019(21.17 \%)$, due to a change in the method of payment of subventions in livestock (which began to be paid per head from that year), a wider range of subjects of subventions (due to the inclusion of heads outside the productivity control programs), as well as greater allocation of funds intended to encourage the formation of producer organizations and marketing and promotion of agricultural products. This changed level and form of support was primarily supposed to contribute to a better appearance of producers on the market.

In addition to the growth of the level of subventions in absolute amount, there came to the largest increase in the share of subventions in this business activity in total expenses and budget expenditures (15.23\%). However, it should be noted that this share did not change significantly and averaged $2.81 \%$ in the observed period. This is a relatively 
low level of support for economic activity that has significant potential for growth and development and that greatly contributes to GDP creation and export. Encouraging the development of entrepreneurship in agriculture should contribute to better use of the potential in this field in the coming period.

\section{Entrepreneurship in agriculture in the Republic of Serbia}

The development of entrepreneurship in the field of agriculture in the Republic of Serbia has not been at a satisfactory level for many years and, therefore, does not contribute to the growth of economic activity and employment as much as it could thanks to the development potential that the Republic of Serbia has. In support of this claim, it can be stated the fact that for years about $80 \%$ of entrepreneurs operate in the so-called non-tradable sectors in which the largest number of workers are employed, as well as a small number of entrepreneurial stores that operate in this business activity. In this regard, Table 4 shows the movement of the number of entrepreneurial stores and their share in the total number of entrepreneurial stores published by the Business Registers Agency (APR) in the Annual Bulletin of Financial Statements.

Table 4. Movement trend of the number of entrepreneurial stores registered in the APR in the period 2015-2019

\begin{tabular}{|l|r|l|l|r|}
\hline Years & $\begin{array}{l}\text { Number of } \\
\text { entrepreneurial stores }\end{array}$ & $\begin{array}{l}\text { Number of } \\
\text { entrepreneurial stores } \\
\text { in agriculture }\end{array}$ & Index & \multicolumn{2}{l|}{ Share } \\
\hline 2015 & 17,286 & 116 & 90.6 & 0.67 \\
\hline 2016 & 17,098 & 122 & 105.2 & 0.71 \\
\hline 2017 & 17,592 & 130 & 106.6 & 0.74 \\
\hline 2018 & 18,594 & 136 & 104.6 & 0.73 \\
\hline 2019 & 108,557 & 827 & 608.1 & 0.76 \\
\hline
\end{tabular}

Source: APR, Annual Bulletin of Financial Statements (relevant issues)

Although the data from Table 4 indicate that there was a significant increase in the number of entrepreneurs in 2019 compared to previous years, it came to such a drastic increase in the number of entrepreneurs due to changes in regulations. In particular, with the Law on Amendments to the Law on Personal Income Tax, most entrepreneurs have changed the way of keeping business books since 2019 (switched from simple to double-entry bookkeeping), as a result of which they started applying the Law on Accounting, so the number of entrepreneurs who report financial statements to APR has increased. Nevertheless, data on the share of entrepreneurial stores in the field of agriculture unequivocally indicate that these entrepreneurs participated in the total number of entrepreneurs with less than $1 \%$ (on average $0.72 \%$ ) during the entire observed period. 
As the number of entrepreneurial activities in the field of agriculture was very low during the observed period, these business entities could not significantly contribute to employment growth. In order to see the movement of the number of employees in entrepreneurial stores in the field of agriculture in the previous period, Table 5 shows the key indicators that indicate the situation in this field in the period 2015-2019.

Table 5. Movement of the number of employees in entrepreneurial stores registered in the APR in the period 2015-2019

\begin{tabular}{|c|c|c|c|c|}
\hline Years & $\begin{array}{l}\text { Number of employees } \\
\text { in entrepreneurial stores }\end{array}$ & $\begin{array}{l}\text { Number of employees } \\
\text { in agricultural } \\
\text { entrepreneurial stores }\end{array}$ & Index & Share \\
\hline 2015 & 46189 & 235 & 114.0 & 0.51 \\
\hline 2016 & 47906 & 262 & 111.5 & 0.55 \\
\hline 2017 & 51546 & 294 & 112.2 & 0.57 \\
\hline 2018 & 57164 & 333 & 115.0 & 0.58 \\
\hline 2019 & 210455 & 1138 & 341.7 & 0.54 \\
\hline
\end{tabular}

Source: APR, Annual Bulletin of Financial Statements (relevant issues)

Based on the data presented in Table 5, it can be concluded that, in this case in 2019, there came to a significant change in the number of employees, but that it was the result of changes in legislation. The share of employees in agricultural entrepreneurial stores in the total number of employees in all entrepreneurial stores was even lower than it was the case with the number of entrepreneurial stores. This frequency also did not change significantly during the observed period and averaged $0.55 \%$.

In order to gain insight into the support to agricultural entrepreneurs, Table 6 shows the movement of incomes from premiums, subventions, donations, etc. granted to entrepreneurs in this business activity in the period 2015-2019, which are stated in the income statements submitted to the APR.

As with the previous two indicators, in this case, due to the change in legislation, it is most reliable to monitor data on the share of incomes from premiums, subventions, donations, etc. granted to agricultural entrepreneurs in the total incomes acquired on this basis in all entrepreneurial stores shown in Table 6. The value of these incomes in agricultural entrepreneurial stores has varied significantly over the years, but if we look at the data on their share in the total incomes of this type, we can see that there have been relatively small changes. During the observed period, agricultural entrepreneurs on average participated in the income on that basis in the amount of $2.34 \%$ per year. 
Table 6. Movement of incomes from premiums, subventions, donations, etc. granted to agricultural entrepreneurs registered in APR in the period 2015-2019

\begin{tabular}{|c|c|c|c|c|}
\hline Years & $\begin{array}{l}\text { Incomes from } \\
\text { premiums, } \\
\text { subventions, } \\
\text { donations, etc. granted } \\
\text { to entrepreneurs }\end{array}$ & $\begin{array}{l}\text { Incomes from } \\
\text { premiums, subventions, } \\
\text { donations, etc. } \\
\text { granted to agricultural } \\
\text { entrepreneurs }\end{array}$ & Index & Share \\
\hline 2015 & 875,226 & 16,327 & - & 1.87 \\
\hline 2016 & 722,660 & 21,077 & 129.1 & 2.92 \\
\hline 2017 & 981,307 & 31,440 & 149.2 & 3.20 \\
\hline 2018 & $1,160,426$ & 26,155 & 83.2 & 2.25 \\
\hline 2019 & $4,450,325$ & 65,790 & 251.5 & 1.48 \\
\hline
\end{tabular}

Source: APR, Annual Bulletin of Financial Statements (relevant issues)

\section{Comparative analysis of business operations of agricultural entrepreneurial stores in relation to entrepreneurial stores in other economic fields within the real sector}

In order to assess the financial position of agricultural entrepreneurs in relation to other entrepreneurs operating in the real sector, a ratio analysis of business operations of entrepreneurs in the following sectors was performed: Sector A - Agriculture, forestry and fisheries; Sector B - Mining; Sector C - Manufacturing industry; Sector D Electricity, gas, steam and air conditioning supply; Sector E - Water supply; wastewater management, control of waste disposal processes and similar activities; Sector F - Construction; Sector G - Wholesale and retail trade; repair of motor vehicles and motorcycles and Sector H - Traffic and storage. The analysis includes three indicators from four key segments of the ratio analysis: liquidity indicators, funds management indicators, profitability indicators and debt management indicators. In this way, it was made possible for each of the segments to be equally included in the analysis. The results obtained on the basis of the ratio analysis are shown in Table 7.

By analyzing the liquidity ratio shown in Table 7, it can be concluded that entrepreneurs in the field of agriculture have a relatively low level of liquidity. The general liquidity ratio is less than 1 , which is most often stated as the lower limit of this indicator. Although slightly lower than the reference value, this value of this indicator indicates insufficient liquidity of entrepreneurs in this business activity. Only sector D records a lower value of this indicator compared to agricultural entrepreneurs, while sector $\mathrm{H}$ does not record a slightly higher value of this indicator. It is often stated in the literature that the minimum value of the rigorous liquidity ratio is 1 , so based on this indicator it can be concluded that agricultural entrepreneurs do not achieve satisfactory liquidity even according to this indicator, although in relation to entrepreneurs in other business activities the situation is somewhat more favorable than in the previous indicator. In particular, entrepreneurs in sectors D (which also have a lower level of liquidity 
according to the general liquidity ratio) and $\mathrm{G}$ (which, due to the high value of stock, achieve significantly worse results in terms of liquidity, although they have a high value of the general liquidity ratio) have worse results according to this indicator. If we take into account the value of net working capital in relation to the value of business assets, it can be concluded that agricultural entrepreneurs have achieved the same results as entrepreneurs from sector $\mathrm{H}$, while entrepreneurs in sector D have significantly worse results according to this indicator.

Table 7. Results of ratio analysis

\begin{tabular}{|c|c|c|c|c|c|c|c|c|}
\hline \multirow{2}{*}{ Ratio analysis indicators } & \multicolumn{8}{|c|}{ Companies by sectors of business activity } \\
\hline & $\mathrm{A}$ & $\mathrm{B}$ & $\mathrm{C}$ & $\mathrm{D}$ & $\mathrm{E}$ & $\mathrm{F}$ & $\mathrm{G}$ & $\mathrm{H}$ \\
\hline \multicolumn{9}{|l|}{ Liquidity indicators } \\
\hline $\begin{array}{l}\text { Current (general) } \\
\text { liquidity ratio }(\mathrm{CR})\end{array}$ & 0.98 & 1.07 & 1.25 & 0.44 & 1.12 & 1.13 & 1.46 & 0.99 \\
\hline $\begin{array}{l}\text { Rigorous liquidity ratio } \\
\text { (QR) }\end{array}$ & 0.67 & 0.94 & 0.68 & 0.30 & 0.70 & 0.81 & 0.49 & 0.87 \\
\hline $\begin{array}{l}\text { Net working capital in } \\
\text { relation to total assets } \\
(\mathrm{NWC})\end{array}$ & -0.01 & 0.03 & 0.13 & -0.54 & 0.07 & 0.08 & 0.27 & -0.01 \\
\hline \multicolumn{9}{|c|}{ Funds management indicators } \\
\hline $\begin{array}{l}\text { Customer turnover ratio } \\
\text { (CTC) }\end{array}$ & 5.26 & 3.81 & 7.55 & 3.91 & 10.78 & 6.04 & 20.89 & 4.60 \\
\hline $\begin{array}{l}\text { Fixed assets turnover } \\
\text { ratio (FAT) }\end{array}$ & 4.78 & 1.78 & 4.80 & 0.45 & 6.94 & 6.01 & 18.60 & 4.34 \\
\hline $\begin{array}{l}\text { Total asset turnover ratio } \\
\text { (AT) }\end{array}$ & 1.54 & 0.99 & 1.64 & 0.26 & 2.50 & 1.65 & 2.79 & 1.69 \\
\hline \multicolumn{9}{|c|}{ Profitability indicators } \\
\hline Net profit margin (NPM) & $4.21 \%$ & $9.25 \%$ & $3.65 \%$ & $-4.51 \%$ & $3.71 \%$ & $5.65 \%$ & $2.17 \%$ & $4.05 \%$ \\
\hline $\begin{array}{l}\text { Return on total assets } \\
\text { (ROA) }\end{array}$ & $7.17 \%$ & $9.10 \%$ & $7.65 \%$ & $-1.72 \%$ & $12.58 \%$ & $15.20 \%$ & $7.52 \%$ & $10.08 \%$ \\
\hline Return on equity (ROE) & $24.58 \%$ & $18.44 \%$ & $15.66 \%$ & $-33.11 \%$ & $28.33 \%$ & $32.39 \%$ & $16.81 \%$ & $22.61 \%$ \\
\hline \multicolumn{9}{|c|}{ Debt management indicators } \\
\hline Debt ratio (DR) & 73.61 & 49.97 & 61.58 & 53.22 & 67.29 & 70.31 & 63,84 & 69.36 \\
\hline $\begin{array}{l}\text { Debt-to-Equity ratio } \\
\text { (DER) }\end{array}$ & 2.79 & 1.01 & 1.61 & 15.09 & 2.06 & 2.45 & 1.77 & 2.29 \\
\hline $\begin{array}{l}\text { Share of long-term } \\
\text { liabilities in total } \\
\text { liabilities (LTD) }\end{array}$ & 4.62 & 8.13 & 8.79 & 0.00 & 10.33 & 6.00 & 5.70 & 7.74 \\
\hline
\end{tabular}

Source: Author's calculation based on data from the Annual Bulletin of Financial Statements 2019

The next group of indicators is the asset management ratios, where the situation is somewhat more favourable in relation to liquidity. Agricultural entrepreneurs have a higher customer turnover ratio and fixed assets turnover ratio in relation to entrepreneurs from sectors $\mathrm{B}, \mathrm{D}$ and $\mathrm{H}$, while according to the value of the total assets turnover ratio they are in a more favourable position only in relation to sectors B and D.

Profitability or profit earning of agricultural entrepreneurs is, according to the level 
of profit rate and ROA, more favourable only in relation to entrepreneurs from sector D, who achieve the worst results according to all three indicators of profitability. As for the value of ROE, the situation is much more favourable, bearing in mind that only entrepreneurs from sectors $\mathrm{E}$ and $\mathrm{F}$ have a higher return on capital compared to agricultural entrepreneurs.

In order to complete the picture of the economy of business operations of entrepreneurs in the field of agriculture, but also of other considered sectors, it is necessary to consider the structure of funding sources. Taking into account the fact that a large number of authors point out that the upper limit of indebtedness is the ratio of capital and debt 1:1 (that is, in the percentage of 50:50), it can be concluded that entrepreneurs in the field of agriculture have the highest level of debt in relation to their own sources, which is indicated by the values of debt ratios and capital structure ratios (leverage). If, on the other hand, the value of the share of long-term debt in borrowed sources is taken into account, it can be concluded that the largest part of borrowed funds of agricultural entrepreneurs represent short-term liabilities. This indicates a serious problem faced by entrepreneurs in this business activity, and that is the inability to finance current business operations from their own sources.

Based on all the above-mentioned, it can be concluded that, taking into account the observed indicators separately, it is not possible to obtain a complete picture of the business operations of these business entities. Therefore, it is necessary to take into account all the observed indicators together for comparative analysis. For that reason, multicriteria analysis was used in this paper, by using the PROMETHEE method, which enables the synthesis of all analysed indicators into one, based on which it is possible to compare the business operations of entrepreneurs from the analysed fields.

\section{PROMETHEE method}

The PROMETHEE method represents a suitable method for solving multicriteria problems that are based on ranking the final set of alternatives based on a number of criteria that need to be maximized or minimized. This method is one of the most commonly used methods of multicriteria analysis, and was developed by Brans, Mareschal and Vincke during the last two decades of the 20th century (Brans, J. P., Mareschal, B.; Brans, J.P. Mareschal, B. Vincke, Ph., 1984; Brans, J.P., Vincke, Ph., 1985; Despotović \& Durkalić, 2017; Durkalić et al., 2019; Đurić et al., 2020). There is almost no scientific field in which this method has not been applied.

This method is based on calculating the net flow of preferences, that is, the values of each alternative expressed in preferences. The net flow of preferences represents a value that synthesizes all indicators and on the basis of which the observed alternatives are ranked. The PROMETHEE method consists of several iterations and there are several versions of this method. In this paper, the PROMETHEE II method will be applied, which implies a complete ranking of alternatives. 
In order for the observed alternatives to be ranked based on the observed criteria, the PROMETHEE method requires defining the appropriate parameters for each of them (Brans, J.P., Mareschal, B. Vincke, Ph., 1984; Brans, J.P., Vincke, Ph., 1985; Brans, J.P. Mareschal, B., 2005):

- Direction of preference - it determines whether a given criterion should be minimized or maximized;

- Weighting coefficients - they indicate the importance of a certain criterion for calculating the net flow of preferences. The higher the value of the weighting coefficient, the more important the criterion is for ranking. In doing so, it should be borne in mind that the sum of all weights should be equal to one;

- Preference threshold (p) - it shows the smallest difference between two alternatives according to a given criterion that the decision maker considers significant for decision making;

- Indifference threshold (q) - it shows the largest difference between the two alternatives according to the observed criterion that the decision maker considers irrelevant for decision making;

- Preference function - the selected function transfers the difference between two alternatives (e.g. alternative 1 and alternative 2) into a preference level ranging from 0 to 1 , for each criterion separately. The closer the level of preference of alternative 1 is to 0 in relation to alternative 2 , the better alternative 2 is in relation to alternative 1 according to the given criterion, and the closer to 1 , the alternative 1 is better than alternative 2 according to the observed criterion.

After defining these parameters, it is possible to rank the alternatives by taking into account all the criteria. In order to get the value of the net flow of preferences, we first calculate the positive flow of preferences (which shows how much a certain alternative is better than the others) and the negative net flow of preferences (which shows how much a certain alternative is worse than the others). Subtracting these two values gives a net flow of preferences, ranging from 1 to -1 . The higher the value of the net flow of preferences of a particular alternative, the better that alternative is compared to the others, and vice versa.

\section{Entropy method}

Bearing in mind that one of the parameters to be defined for the application of this method is the weighting coefficient for each criterion, the entropy method has been applied for this purpose in this paper. Objectively defined weighting coefficients are usually used when applying multicriteria analysis for conducting comparative analysis, while subjectively determined weighting coefficients are most often used in cases when ranking alternatives is done for decision making based on decision maker preferences. The application of the entropy method enables the objective defining of weight coefficients, and thus a more objective ranking of the observed alternatives. Determining the weight of the criteria based on this method is based on measuring the uncertainty of information in the decision matrix. 
The application of this method is based on the calculations of the entropy value, on the basis of which the value of the weight coefficient for each criterion is later calculated. The criterion for which a lower value of entropy is obtained provides more information for decision making, and accordingly it has a greater significance for decision making, that is, the final ranking of alternatives. When determining the weight parameters, it is started from the defined decision matrix, on the basis of which the normalization of data is first performed. Then the entropy value is calculated for each criterion, in order to finally determine the weight of all criteria based on it.

\section{Setting up a multicriteria analysis model}

Before the application of the PROMETHEE method, it is necessary to define the already mentioned parameters of multicriteria analysis, on the basis of which the ranking of entrepreneurial stores from the observed sectors was performed. The values of weight coefficients were determined by using the entropy method, which together with other parameters of multicriteria analysis are shown in Table 8.

Table 8. Defined parameters of multicriteria analysis

\begin{tabular}{|c|c|c|c|c|c|c|}
\hline \multirow[b]{2}{*}{ Parameters } & \multicolumn{3}{|c|}{ Liquidity indicators } & \multicolumn{3}{|c|}{ Funds management indicators } \\
\hline & $\mathrm{CR}$ & QR & NWC & СТC & FAT & AT \\
\hline $\begin{array}{l}\text { Direction of } \\
\text { preference }\end{array}$ & Max & Max & Max & Max & Max & Max \\
\hline $\begin{array}{l}\text { Weighting } \\
\text { coefficient }\end{array}$ & 0.06 & 0.08 & 0.06 & 0.12 & 0.09 & 0.08 \\
\hline $\begin{array}{l}\text { Preference } \\
\text { function }\end{array}$ & Linear & Linear & Linear & Linear & Linear & Linear \\
\hline $\begin{array}{l}\text { Indifference } \\
\text { threshold }\end{array}$ & 0.26 & 0.17 & 0.24 & 5.65 & 5.41 & 0.64 \\
\hline \multirow[t]{2}{*}{$\begin{array}{l}\text { Preference } \\
\text { threshold }\end{array}$} & 0.59 & 0.41 & 0.48 & 11.49 & 11.05 & 1.56 \\
\hline & \multicolumn{3}{|c|}{ Profitybility indicators } & \multicolumn{3}{|c|}{ Indebtedness indicators } \\
\hline Parameters & NPM & ROA & ROE & DR & DER & LTD \\
\hline $\begin{array}{l}\text { Direction of } \\
\text { preference }\end{array}$ & $\operatorname{Max}$ & $\operatorname{Max}$ & $\operatorname{Max}$ & $\operatorname{Min}$ & Min & Min \\
\hline $\begin{array}{l}\text { Weighting } \\
\text { coefficient }\end{array}$ & 0.06 & 0.07 & 0.07 & 0.10 & 0.12 & 0.07 \\
\hline $\begin{array}{l}\text { Preference } \\
\text { function }\end{array}$ & Linear & Linear & Linear & Linear & Linear & Linear \\
\hline $\begin{array}{l}\text { Indifference } \\
\text { threshold }\end{array}$ & 3.57 & 4.33 & 21.44 & 6.44 & 5.38 & 2.62 \\
\hline $\begin{array}{l}\text { Preference } \\
\text { threshold }\end{array}$ & 7.70 & 9.85 & 41.06 & 16.36 & 9.19 & 6.27 \\
\hline
\end{tabular}


Based on Table 8, it can be concluded that the highest weighting coefficient has been obtained for CTC and DER (0.12), which indicates that the largest differences among entrepreneurs from different business activities exist in this indicator, while the smallest differences are present in the amount of CR, NWC and NPM (0.06). The preference function and the preference and indifference thresholds were determined with the help of the Visual PROMETHEE software package, which proposed the given parameters based on the characteristics of the entered data set.

\section{Results and discussion}

By applying the mentioned parameters, the ranking of entrepreneurs from selected sectors of business activity was performed, in order to gain insight into the differences in the efficiency of business operations of agricultural entrepreneurs and entrepreneurs from other considered business activities. Table 9 shows the movement of positive, negative and net flow of preferences and the ranking of entrepreneurs from selected business activities on the basis of all observed indicators together.

Table 9. Results of the PROMOETHEE method

\begin{tabular}{|c|c|c|c|c|}
\hline Rank & action & Phi+ & Phi- & Phi \\
\hline 1 & G & 0.3575 & 0.0727 & 0.2847 \\
\hline 2 & B & 0.1994 & 0.0777 & 0.1217 \\
\hline 3 & F & 0.1209 & 0.0829 & 0.0380 \\
\hline 4 & E & 0.1265 & 0.0917 & 0.0348 \\
\hline 5 & C & 0.0978 & 0.0827 & 0.0152 \\
\hline 6 & $\mathrm{H}$ & 0.0991 & 0.0939 & 0.0052 \\
\hline 7 & A & 0.0965 & 0.1151 & -0.0185 \\
\hline 8 & D & 0.1269 & 0.6079 & -0.4810 \\
\hline
\end{tabular}

Source: Author's calculation.

Based on the results shown in Table 9, it can be concluded that the best ranked entrepreneurs are in sector $G$, while agricultural entrepreneurs are ranked in the penultimate place. Only entrepreneurs from sector D achieve worse results. It should be emphasized that only the two worst ranked sectors have a negative net flow of preferences, which indicates that the limitations in business operations of entrepreneurs from these business activities outweigh the advantages they have over entrepreneurs from other sectors. These ranking results indicate that entrepreneurs operating in the field of agriculture face numerous limitations in doing business, which slows down the development of entrepreneurship in this business activity. In order to see the advantages and limitations of business operations of entrepreneurs in this sector, Figure 1 shows the profile of this business activity obtained in the Visual PROMETHEE software package. 
Figure 1. Advantages and limitations in the business operations of agricultural entrepreneurs in relation to entrepreneurs from other business activities

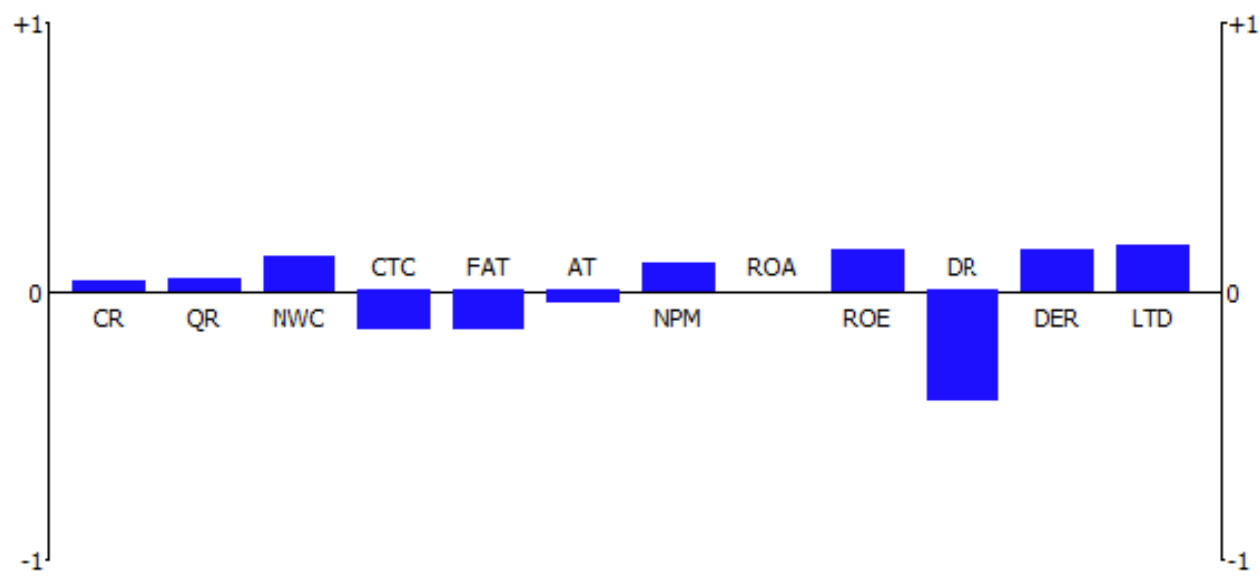

Source: Author's calculation.

Based on the results shown in Figure 1, it can be concluded that the key limitations in the business operations of these entrepreneurs relate to inefficient funds management, given that the chart shows all three pillars indicating the mentioned group of indicators facing down. In addition, indebtedness represents a significant limitation for these entrepreneurs. The biggest limitation in business operation represents the large share of borrowed capital in the structure of funding sources. It should be noted that although the column showing leverage is up, it is not a significant advantage of this sector, but such results were obtained due to significantly better results achieved compared to sector D, where leverage is extremely high, due to high losses above capital, despite the relatively low share of liabilities in total liabilities.

\section{Conclusion}

Numerous problems that exist in the agriculture of the Republic of Serbia impose as an imperative the adoption of a long-term development policy in the field of agriculture. Adoption of long-term development policy in agriculture implies certain changes, in terms of business conditions, pricing policy, credit and tax support mechanisms. The most important aspect of creating a long-term development policy in the field of agriculture should be a substantial change in the current attitude towards agriculture, in the sense that agricultural production with all its specifics is treated equally with other economic fields.

In addition, the slow turnover of capital invested in agriculture makes it necessary to have constant funding sources, due to the seasonal character of this production. The seasonal character of agricultural production requires the need for successive engagement of means for production and stocks. Precisely because of that, the request for additional (external) funding sources for this production is permanently present. In addition to this specificity, the necessity of state support arises from the fact that the 
investment of funds is made successively, due to the existence of time inconsistency of costs invoiced in agriculture and the opportunities for agriculture to cover these costs through its implementation. A special problem represents the poor organization of business operations in this business activity. There is a small number of entrepreneurial stores. There is still a large share of natural production. Commodity production is growing, but at a slow pace. To this should be added the rather unregulated market of agricultural products. There is monopolistic behaviour and the absence of healthy competition. These are all weaknesses that agriculture as a whole is still facing, and which should be eliminated in the upcoming period. In addition, it is necessary to provide support to young agriculturists in order to prevent deagrarization and demographic depopulation of villages, and introduce quality standards for agricultural products and create conditions for sustainable agricultural production.

\section{Conflict of interests}

The authors declare no conflict of interest.

\section{References}

1. Aničić, D., Obradović, M., \& Vukotić, S. (2018). Impact of economic policy on the management of competitiveness of the agriculture sector in Serbia. Economics of Agriculture, 65(1), 187-200. https://doi.org/10.5937/ekoPolj1801187A

2. APR, (2020). Annual report on business operations of the economy in 2019, available at: https://www.apr.gov.rs/upload/Portals/0/GFI_2020/Makroekonomska _saopstenja/Godisnji_izvestaj_o_poslovanju_privrede_u_2019.pdf

3. APR, Annual Bulletin of Financial Statements, available at: https:/www.apr. gov.rs/registri/finansijski-izvestaji/publikacije/godisnji--bilten-finansijskihizvestaja.2127.html

4. Dimitrijević, M., Vržina, S., \& Leković, M. (2020). Agricultural enterprises and economic growth: A regional analysis in the Republic of Serbia. Economics of Agriculture, 67(2), 585-600. https://doi.org/10.5937/ekoPolj2002585D

5. Despotović, D., \& Durkalić, D. (2017). Analysis of budget deficit in the candidate countries for EU membership. Serbian Journal of Management, 12(2), 237-253.

6. Durkalić, D., Furtula, S., Borisavljević, K. (2019), Ranking tourism market perfomance in EMU countries: results of PROMETHEE - GAIA approach, Hotel and Tourism Management, 7(2), 67-76, https://doi:10.5937/menhottur1902067D

7. Đurić, K., Tomaš-Simin, M., Glavaš-Trbić, D., \& Lukač-Bulatović, M. (2020). Challenges of the common agricultural policy of the European Union in the period after 2020. Economics: theory and practice, 13(3), 34-47.

8. Đurić, K., Prodanović, R., Čavlin, M., \& Lukač-Bulatović, M. (2020). Economic performance of agroindustry in AP Vojvodina. Oditor - časopis za menadžment, finansije i pravo, 6(2), 7-19. https://doi.org/10.5937/Oditor2002007D 
9. Ilić, V., Bauer, I., Djelić, A. T., \& Nešković, A. (2017). Institutional support for strengthening entrepreneurship in agricultural production of the Republic of Serbia. Economics of Agriculture, 64(4), 1537-1554. https://doi.org/10.5937/ ekoPolj1704537I

10. Jurjević, Ž., Bogićević, I., Djokić, D., \& Matkovski, B. (2019). Information technology as a factor of sustainable development of Serbian agriculture. Strategic management, 24(1), 41-46.

11. Kuzman, B., Djurić, K., Mitrović, L., \& Prodanović, R. (2017). Agricultural budget and agriculture development in Republic of Serbia. Economics of Agriculture, 64(2), 515-531. https://doi.org/10.5937/ekoPolj1702515K

12. Law on Agriculture and Rural Development, Official Gazette of RS, no. 41/09, 10/13-state law and 101/16

13. Law on Amendments to the Law on Personal Income Tax, Official Gazette of RS no. 113/2017.

14. Miskic, M., Njegomir, V., \& Stojic, D. (2018). Agricultural entrepreneurship and production risk management in serbian farms. CUSTOS E AGRONEGOCIO ONLINE, 14(3), 254-268.

15. National Program for Agriculture for the period 2018-2020, Official Gazette of RS, no .120/17

16. Njegomir, V., Tepavac, R., \& Ivanišević, N. (2017). Alternative sources of financing entrepreneurial undertakings in agriculture. Economics of Agriculture, 64(1), 295 306. https://doi.org/10.5937/ekoPolj1701295N

17. Prodanović, R., Kuzman, B., Jahić, M., \& Đurić, K. (2018). Objectives, possibilities and limitations of the IPARD II proram in the development of the agrarian sector of the Republic of Serbia. Business School Magazine, (2), 149-164.

18. RZS (Statistical Office of the Republic of Serbia), 2020. Monthly statistical bulletin, https://publikacije.stat.gov.rs/G2021/Pdf/G20213001.pdf

19. RZS (Statistical Office of the Republic of Serbia), 2020. Monthly statistical bulletin, https://publikacije.stat.gov.rs/G2021/Pdf/G20213001.pdf

20. RZS (Statistical Office of the Republic of Serbia), 2020. Monthly statistical bulletin, https://publikacije.stat.gov.rs/G2021/Pdf/G20213001.pdf

21. RZS (Statistical Office of the Republic of Serbia), 2020. Monthly statistical bulletin, https://publikacije.stat.gov.rs/G2021/Pdf/G20213001.pdf

22. Strategy of Agriculture and Rural Development of the Republic of Serbia for the period 2014-2024, Official Gazette of RS, no. 85/14

23. Sekulić, N.M., Živadinović, J., \& Dimitrijević, L. (2018). Concerns about hamonization process of Serbian agricultural policy with EU standards. Economics of Agriculture, 65(4), 1627-1639. https://doi.org/10.5937/ekoPolj1804627M 
